with their publications at the fraction of their usual cost - perhaps one copy of each of the scientific journals to each of the countries.

But the simplest proposal in my opinion would be the one which the Chinese have adopted. In China, all scientific journals and books are reprinted at Hefei University and sold for a fraction of their price - usually one-third of a dollar. This be done because the country does not yet adhere to the copyright law. For the same reason, the university does not supply anyone else outside China. So far as journals are concerned, the university is supplying them to a set of people who would otherwise not be able to afford them.

What has been proposed so far is still limited in scope. At the Third General Conference of TWAS in November 1990, I suggested the establishment of central libraries in those developing countries where they do not yet exist. This proposal is based on my belief that every developing country should have at least one complete and up-to-date library. As a first step it was further suggested that the academy should start with a pilot project involving 5-10 countries, among them Egypt, Jordan, Morocco, Sudan, Syria. Tunisia and Turkey, with the support of international organizations. Professor Federico Mayor, director general of UNESCO, agreed that the organization would consider contributing an initial sum of 500,000 dollars. A feasibility study will begin soon. Members of the Italian Government have expressed their interest in this project, which fits the targets of the Italian programme for cooperation to development. If only governments of other industrialized countries of the north had this farsighted attitude.

To end, many authors of scientific books published by US, British or French companies are expatriates from developing countries, and they have achieved success and reputation in their new country. To them, I suggest they find a way in their contract with the publishers so that their work can also be printed cheaply in their country of origin.

New technology for the storage of information, CD-ROM for example, is useful and will become even more so in the future. But for many years still, books and journals will remain the vehicles of the written word in the everyday life of professional scientists. We must therefore solve the problem of how to provide the developing countries with these vehicles if science is to flourish there.

Abdus Salam is at the International Centre for Theoretical Phy'sics, PO Box 586, 34100 Trieste, Italy.

\title{
New journals review 1991
}

CRITERIA for journals to be considered for review in this issue were circulated to publishers earlier this year, and were also published in Nature. They were that:

(1) the first number appeared between June 1989 and May 1990, with four issues available by May 1991 (although journals not covered in last year's review issue were also considered)*;

(2) the journal is published at least three times a year;

(3) the main language used is English;

(4) where possible at least four issues should be made available for review, including the first and the most recent numbers.

Last year's journals review supplement covered publications appearing between June 1988 and May 1989, with four issues available by May 1990. The second cut-off date allows for enough issues of a journal to have been published for a reasonable sample to be available for judgement at the time of commissioning reviews.

Severals journals known to satisfy the above criteria were not submitted for review, or arrived too late for inclusion. It proved difficult to find reviewers for other, doubtless worthy journals, while

\section{Reviews index}

American Journal of Physiology: Lung Cellular and Molecular Physiology Anti-Cancer Drugs: An international Journal on Anti-Cancer Agents Arabic Sciences and Philosophy

Applied and Theoretical Electrophoresis

Behavioural Ecology

Bioconjugate Chemistry

Biodegradation

Biotechnology Therapeutics

Biomedical Science

Bioseparation

Cancer Causes and Control

Cell Regulation

Cerebral Cortex

Comments on Developmental Neurobiology

Computational Mathematics and Modeling

Cytokine

Dementia

Discovery and Innovation

DNA Sequence: The Journal of DNA Sequencing and Mapping

Ecological Economics

Experimental Astronomy

Hippocampus

International Journal of Foundations of Computer Science

International Journal of Neural Systems

Journal of Biomolecular NMR

Journal of Computer-Assisted some titles were considered to be of marginal interest to Nature's audience. Abstracts publications and newsletters are not reviewed. A list of titles eligible for review but not covered appears on page 481 .

The brief given to the reviewers was to limit themselves to comment on the publications sent to them, and to avoid discussion of general questions of periodical publishing. Opinions expressed in the reviews are based on a sample of issues, and apply to mid-1991 at the latest. As in previous years, the preponderance of journals in the biological sciences reflects the bias of material submitted for review.

Details of editors and frequency of publication, and the subscription rates appearing at the top of each review, are given in most instances for 1991. This information is not complete in all cases, and readers interested in subscribing to a particular journal should check the rates with the publisher concerned.

* See Nature 347, 581-599 (1990); 341, 350370 (1989); 335, 459-478 (1988); 329, 357-376 (1987); 323, 359-379 (1986); 317, 293-308 (1985); 311, 309-330 (1984); 305, 477-497 (1983); and 299, 491-514 (1982).

Microscopy 471

Journal of Essential Oil Research $\quad 475$

Journal of Intelligent Manufacturing $\quad 476$ Journal of Materials Chemistry 473

Journal of Materials Science:

Materials in Electronics

Journal of Materials Science:

Materials in Medicine

Journal of Neuroendocrinology

Journal of the History of Sexuality

Journal of Visual Language and Computing

Land Degradation and Rehabilitation

Mathematical Structures in Computer Science

Measurement Science and Technology 476

Methods: A Companion to Methods in Enzymology

Molecular and Cellular Neurosciences 462 Neuroreport 463

Polycyclic Aromatic Compounds 472

Polymers for Advanced Technologies 473

Protein Expression and Purification

Quantum Optics

Reviews in Mathematical Physics $\quad 478$

Seminars in Cancer Biology $\quad 467$

Seminars in Cell Biology

480 Seminars in Developmental Biology

Seminars in the Neurosciences 463

462 Seminars in Virology 466

Structural Chemistry $\quad 472$

477 The European Journal of Neuroscience 463

Trends in Food Science and

Technology

477

Vibrational Spectroscopy: A Section of Analytica Chimica Acta 